\title{
Gender and Specialization Differences of Business Students in Self -Estimates of Multiple Intelligences
}

\author{
Ra'ed Abdelkarim \\ Khedr Abo Hassan \\ Reem Abuiyada \\ College of Arts and Applied Sciences \\ Dhofar University, Salalah \\ Oman
}

\begin{abstract}
This study explores multiple intelligences profiles among Business students at Dhofar University and investigates the differences in students' multiple intelligences according to specialization (Accounting \&Finance, Management\& Marketing, and Management Information System) and gender. This study was held at Dhofar University (DU) in the fall of the 2017-2018. The students were from the first year Bachelor and Diploma programs. A scale of Multiple Intelligences developed by the researcher was applied on (68) students. Mean, standard deviation and MANOVA test were used for statistical analysis. The study shows that intrapersonal intelligence has the highest score and ranks first always. Also, the study shows that there are statistically significant differences in Linguistic intelligence in favor of Management and Marketing (M\&M) and in Interpersonal intelligence in favor of Management Information Systems (MIS) specialization
\end{abstract}

Keywords: Multiple Intelligences, Gender, Fields of Specialization, Business Students.

Intelligence is an important concept in many disciplines (Psychology, Education, Sociology, and many others). The concept has been defined and redefined many times. Francis Galton (as cited Sternberg, 1990) reported that intelligence related neurological efficiency. Which means that the intelligence could be examined by measuring the time of the reaction and sensory acuity?

"Intelligence is the aggregate or global capacity of the individual to act purposefully, to think rationally and to deal effectively with his environment (Wechsler, 1944)." which means that the term intelligence is not a single ability.

According to Vygotsky, the individual's development is a result of his or her culture. Vygotsky felt social learning precedes development. He states: "Every function in the child's cultural development appears twice: first, on the social level, and later, on the individual level; first, between people (interpsychological) and then inside the child (intrapsychological)", (Vygotsky,1978).

In 1983, Gardner published his theory: Frames of Mind: The Theory of Multiple Intelligences. The revolutionary idea of this theory is the idea of diversity. Gardner claimed that we have seven intelligences functioning independently. This new idea was against the traditional understanding of intelligences which was focusing on one or two capacities.

In order for any capacity to be labeled as intelligence, Gardner set clear and specific criteria. The criteria have different roots as follow: (Gardner ,1999).

a. biological root:

1. Potential isolation by brain damage.

2.An evolutionary history and an evolutionary plausibility.

b. logical root:

3. An identifiable core operation or set of operations.

4. Susceptibility to encoding from a symbol system.

c. developmental psychology root: 
5. A distinctive developmental history with a definite set of "end state" performances.

6. The existence of idiot, savants, prodigies and other exceptional people.

d. traditional psychological root:

7. Support of experimental and psychological tasks.

8.Support from psychometric findings.

Armstrong (2009) claimed that MI theory represents a good tool to help the young people begin to think and select their career aspirations. He suggested that students in high schools can be involved in an ongoing process of self-assessment to find out or identify what jobs are suited for them. One of the most important and useful selfassessment is multiple intelligences assessment. Following is career guidance based on multiple intelligences:

- Visual-Spatial Intelligence (Picture smart): Architects, Interior Designers, Fashion Designers, Photographers, Painters, Animators.

- Bodily-Kinesthetic Intelligence (Body Smart): Actors, Dancers, Athletes, Yoga Teachers, Fire fighters, Police Force.

- Logical Mathematic Intelligence (Number Smart): Engineers, Scientists, Economist, Auditor, Accountant, Bookkeeper, Math or science teacher.

- Musical-Rhythmic Intelligence (Music Smart): Musician, Instrument maker, Piano tuner, Songwriter, Studio engineer, Singer, Music teacher.

- Verbal-Linguistic Intelligence (Word Smart): Librarian, Archivist, Writer, TV announcer, Journalist, Lawyer, Proofreader, Language teacher.

- Naturalist Intelligence (Nature Smart): Wild life photographer, Zoologist, Naturalist, Marine biologist, Farmer, Ecologist, Nature guide.

- Interpersonal Intelligence (People Smart): Educators, Manager, Coach, HR-Professionals, Politicians, Sociologist, Counselor, Nurse, Public relations person, Travel agent.

- 8. Intra-personal Intelligence (Self Smart): Psychologist, Clergyman, Psychology teacher, Therapist, Counselor, and Entrepreneur.

\subsection{Statement of the Problem:}

If every learner understands his uniqueness in the classroom, he will increase his opportunities for learning and his ability in aligning his potentials to specific tasks. 'Multiple intelligences' is one aspect of a learner's uniqueness. Actually, MI theory assumes that if there are programs that demonstrate the skills of real life in the eight intelligences for individuals from an early age then the individuals will have clear and more reliable bases to select the future career. (Armstrong, 2009). The study will examine the differences in multiple intelligences of business students at DU in term of gender and the chosen field of specialization.

\subsection{Research Questions:}

1. What are the multiple intelligences profiles of business students?

2. What are the multiple intelligences profiles of business students according to the gender?

3. What are the multiple intelligences profiles of business students according to the field of specialization?

4. What are the differences in the multiple intelligences profiles of business students according to gender, and field of specialization?

\subsection{Research Hypotheses}

From the last question, two hypotheses emerged:

1. There are no statistically significant differences at $(\alpha=0.05)$ in the multiple intelligences of the profiles of business students attributed to gender.

2. There are no statistically significant differences at $(\alpha=0.05)$ in multiple intelligences of the profiles of business students attributed to the field of specialization.

\subsection{Significance of the Study:}

Currently, the theory of Multiple Intelligences is considered as an effective tool in determining the diversity of the learners all over the world. This study highlights the relationship between multiple intelligences profiles and field of specialization. This issue is very important for the higher education students and it could be crucial for the student before selecting the college or the field of specialization. 
To the knowledge of the researcher, this is the first study explores the multiple intelligences profiles of business students in Dhofar provenance in Sultanate of Oman. It is hoped that this study represents an indicator for the business study to know if they are accommodated in the right specialization or not.

It is also hoped that this study will encourage educators to embrace in their teaching the idea that students are gifted with multiple intelligences besides mathematical and linguistic abilities. The teachers' awareness of the students' different ways in which students demonstrate their understanding of materials can help them design various experiential and successful learning activities and contextualized instructional materials that will make them excel in and suit to their area of interest.

Enlighten the students in the high school or first-year students about the theory of multiple intelligences will help the student to choose the appropriate college and the specialty which match his or her intelligences profile. If the multiple intelligences scale is administered at the end of the high school or in the first year of the university, then the students will be more aware of their capabilities, skills, and intelligences and hence the chance of completing the university will be very high and consequently, the drop-out rate will be descending.

\subsection{Study Limitations}

- A sample of males and females of business students in Dhofar University.

- The validity and reliability of the instrument that is used in the study.

1.6 Operational Definitions of Study’s Terminology: (Gardener, 1983, 1993, 1995, 1999)

Verbal-Linguistic Intelligence: refers to an individual's ability to display a facility with words and languages. They are typically good at reading, writing, and telling stories. They have the ability to explain, teach, and they can learn a foreign language very easily.

Mathematical-Logical Intelligence: refers to an individual's who are naturally excel in mathematics, computer programming and other logical reasoning.

Musical Intelligence: refers to individuals who display greater sensitivity to sounds, rhythms, tones, and music. People with strong musical intelligence normally have a good pitch and are able to sing, play musical instruments, and compose music.

Visual-Spatial Intelligence: refers to the ability to visualize and mentally manipulate objects. People with strong visual-spatial intelligence have a strong visual memory and are often artistically inclined. BodilyKinesthetic Intelligence: refers to the ability to enjoy acting or performing. people with strong bodily-kinestheticintelligence often learn best by physically doing something. Bodily-Kinesthetic Intelligence is measured by the test of multiple intelligences Interpersonal Intelligence: The ability to communicate effectively and empathize easily with others. People with strong Interpersonal Intelligence are usually extroverts and are characterized by their sensitivity to others' moods, feeling, and motivation. Intrapersonal Intelligence: the ability to have highly self- aware People with strong Interpersonal Intelligence can understand their own emotions, goals, and motivations. Naturalist Intelligence: refers to individuals who have greater sensitivity to nature. They are good at taming and interacting with animals.

\section{Theoretical Literature and Related Studies:}

\subsection{Multiple Intelligences:}

Since it was published in 1983, MI theory challenged the traditional perception of intelligence which was basically recognizing one or two types of intelligences. MI theory emphasizes and promotes the idea of diversity and highlights the several ways way of employing these intelligences to developing the society and its advancement. (Kallenbach, 2006; Gardner, 2011).

All of us have abilities. We are strong in some abilities and weak in others. To develop our abilities, it's very important to select the best mean or best tool. Multiple Intelligences theory (MI) defines the intelligence based on three components: (1) Intelligence is a set of skills that can be used to solve problems or overcome difficulties (2) Intelligence is considered if there is an achieving of a product valued by the culture (3) Intelligence is considered when reaching a creative solution leads to new knowledge. (Gardner ,1983).

Armstrong (2009) displayed in details the intelligences of MI theory in his book "Multiple Intelligences in The Classroom". Armstrong highlighted some important point regarding the theory. These points are: (1) MI theory suggests that there are many intelligences, not just one intelligence. 
Each one of us possess the eight intelligences and they work together in an amazing and unique way (2) With encouragement, training, and appropriate program, most people can develop any intelligence to a good level of competency (3) All intelligences are functioning together in a complicated way (4) No standard features exist for anyone to be smart or intelligent in any field. Some people don't have the ability to read or write, but he is a great poet or a famous orator.

There are some important key points explain the essence of MI theory: (1) Despite that every one of us possess the eight intelligences, we are all different because the strength of each intelligence is varying and that's why everyone has a different intelligences profile (2) The intelligences could work together smoothly or each intelligence works independently (3) Education can be improved if the materials and learning activities are designed based on the intelligences profile of the students. Gardner announced his theory starting with seven intelligences. Later he added two more intelligences (Gardner, 1999)

This theory has been the framework of the study. This research explores the multiple intelligence profiles of the students. It considers eight intelligences and excludes existential intelligence because accordingly, many educators still hesitate to accept it as intelligence in the classroom.

\subsection{Previous related studies:}

Kandeel (2016) conducted a study to find out the patterns of multiple intelligences of students and how it is related to the academic achievement in Mathematics course at King Saud. The results ranked the multiple intelligences of the study sample as self, social, bodily, logical, verbal, visual, musical and natural intelligence.

Fardad, Koosha, and Shafiee (2015) explored the relationship between (MI) scores of EFL students according to their gender and their vocabulary knowledge. The sample of the study consisted of 88 students (24 males and 64 females) from Khorasgan Azad University. The results show that there is no significant relation between MI scores and their vocabulary knowledge. Also, the study revealed that no significant difference between males and females concerning different types of intelligences

Mustafa, Abu Jado, and Onoz (2014) conducted a research to explore the multiple intelligences type of Jordanian students at Yarmouk University. The researchers used the Multiple Intelligences Test (MIT) prepared by Onoz (2009). (759) students from Yarmouk University participated in the study. The results revealed that the linguistic intelligence came first, while the spatial intelligence came last.

Al-Faoury, Khataybeh, and Al-Sheikh (2011) studied the intelligences types of the Jordanian students in different public and private universities. To collect data, the researchers used a survey which was administered to (1436) students. The results showed that females excelled in linguistic and interpersonal intelligence. Also, the results showed that there were significant differences in the logical intelligences in favor of the governmental universities. Regarding the average factor, the study didn't find any significant differences in the multiple intelligences could be attributed to the average.

Al-Aslani (2010) conducted a study to explore the impact of using a remedial strategy based on MI theory on improving the achievement in the geometry of slow learners. Attitudes towards geometry also have been investigated. The results showed that the remedial strategy has a positive effect and the performance of the experimental group is better than the performance of control group.

Ahmad (2010) explored the impact of a program designed according to MI theory on improving the academic achievement and developing the creative thinking of students in secondary commercial school. The number of participants was (120) female students. The sample was divided into (40) students represented the control group, and (80) students represented the experimental group. The results showed that the program has a positive effect and the performance of the experimental group is better than the performance of control group.

Alumran (2006) explored the multiple intelligences of the students at University of Bahrain and investigated the difference in multiple intelligences with respect to gender and the field of specialization. The researcher developed a multiple intelligences test to find out the intelligences profiles. The participants were (238) students from (13) different specializations. Using MANOVA, results found that dominant intelligences were social intelligence and Personal intelligence.

\section{Methodology}

\subsection{The study sample:}


The sample of this study is business students from College of Commerce and Business Administration (CCBA) at Dhofar University (DU). The students were from the first year Bachelor morning programs and they were selected randomly from different specializations. The total number of the first-year student in CCBA is (761) from all specializations. The population of this study composed of (68) which represents $8.94 \%$.College of Commerce and Business Administration (CCBA)consists of three departments: Accounting and Finance (A\&F), Management and Marketing (M\&M), and Management Information Systems (MIS). Table (1) shows the distribution of the study sample according to gender and field of specialization.

Table 1: Distribution of sample in terms of gender and the field of specialization:

\begin{tabular}{|l|l|l|l|}
\hline & Category & Number & Percent \% \\
\hline \multirow{4}{*}{ Gender } & Males & 32 & 47.1 \\
\cline { 2 - 4 } & Females & 36 & 52.9 \\
\cline { 2 - 4 } & Total & 68 & 100.0 \\
\hline \multirow{3}{*}{$\begin{array}{l}\text { Specialization } \\
\end{array}$} & Accounting and Finance (A\&F) & 20 & 29.4 \\
\cline { 2 - 4 } & Management and Marketing (M\&M) & 22 & 32.4 \\
\cline { 2 - 4 } & Management Information Systems (MIS) & 26 & 38.2 \\
\cline { 2 - 4 } & Total & 68 & 100.0 \\
\hline
\end{tabular}

\subsection{Study Instruments and test scoring: Multiple Intelligences Scale}

After reviewing the literature and studying some inventories related to MI theory, the researchers developed a scale to measure the MI profile of the students. the scale developed mainly by taking advantage of Mackenzie (1999), Armstrong (2009) and Abdulkarim \& Al Jadiry (2012). Five Likert scale has been used: always apply, apply, apply sometimes, do not apply, and never apply. The maximum weight is (5) and it is given to the response always apply while the minimum is given (1) to the response never apply. The MI scale is written in both languages English and Arabic.

\subsection{Tool validity}

To confirm the validity, the scale has examined first by seven professors (The specializations of professors are: Psychology, Measurement, and Evaluation, Curricula and instruction) The comments and suggestions of the referees have been studied and the final version of the scale has developed in both languages: Arabic and English then sent to English language teacher and Arabic language teacher for final revision.

\subsection{Tool Reliability:}

Regarding the reliability, the researchers applied the scale on an exploratory sample of 23 students. The reliability coefficient is calculated by using Cronbach Alpha. Table (2) explains the values coefficients for each intelligence.

Table 2: Cronbach Alpha coefficients for each intelligence

\begin{tabular}{|l|l|l|l|}
\hline No. & Intelligence & Number of Items & Value of Cronbach alpha coefficient \\
\hline 1 & Linguistic Intelligence & 8 & 0.84 \\
\hline 2 & Logical-Mathematical Intelligence & 8 & 0.92 \\
\hline 3 & Spatial Intelligence & 8 & 0.75 \\
\hline 4 & Kinesthetic Intelligence & 8 & 0.89 \\
\hline 5 & Musical Intelligence & 8 & 0.93 \\
\hline 6 & Interpersonal Intelligence & 8 & 0.74 \\
\hline 7 & Intrapersonal Intelligence & 8 & 0.90 \\
\hline 8 & Naturalist Intelligence: & 8 & 0.83 \\
\hline
\end{tabular}

\subsection{Study Procedures:}

The following procedure was implemented:

1. Preparing the MI scale after reviewing the theoretical literature

2. Getting the consents from the research department to conduct the study.

3. calculating validity and reliability of the scale.

4. Selecting the sample from undergraduate business students at Dhofar University (First year morning program).

5. administering the scale on the study sample. 
6. interviewing the students.

7. The statistical analyzing processing.

\subsection{Study Variables:}

1. Independent variables:

1) Gender (Males, females)

2) Specializations of the students

2. Dependent variable: The intelligences of students

\subsection{Data Analysis:}

(SPSS) program has been used to calculate the means and standard deviation. M ANOVA Test was also used to find out if the differences in multiple intelligences profiles were significant or not.

\section{Results and discussion:}

\section{1: Findings and discussions of the first question:}

The first question was: What are the multiple intelligences profiles of business students? Table (3) shows means, standard deviation, and the rank of the sample while figure (1) shows a column chart of the results.

Table 3: multiple intelligences profiles of the sample

\begin{tabular}{|l|l|l|l|}
\hline Type of Intelligence & Mean & STDEV & Rank \\
\hline Linguistic & 28.00 & 4.429 & $3^{\text {rd }}$ \\
\hline Logical & 27.04 & 4.490 & $4^{\text {th }}$ \\
\hline Spatial & 25.81 & 5.320 & $6^{\text {th }}$ \\
\hline Kinesthetic & 26.94 & 4.574 & $5^{\text {th }}$ \\
\hline Musical & 22.93 & 6.940 & $8^{\text {th }}$ \\
\hline Interpersonal & 28.66 & 5.000 & $2^{\text {nd }}$ \\
\hline Intrapersonal & 30.43 & 4.516 & $1^{\text {st }}$ \\
\hline Naturalist & 25.49 & 6.016 & $7^{\text {th }}$ \\
\hline
\end{tabular}

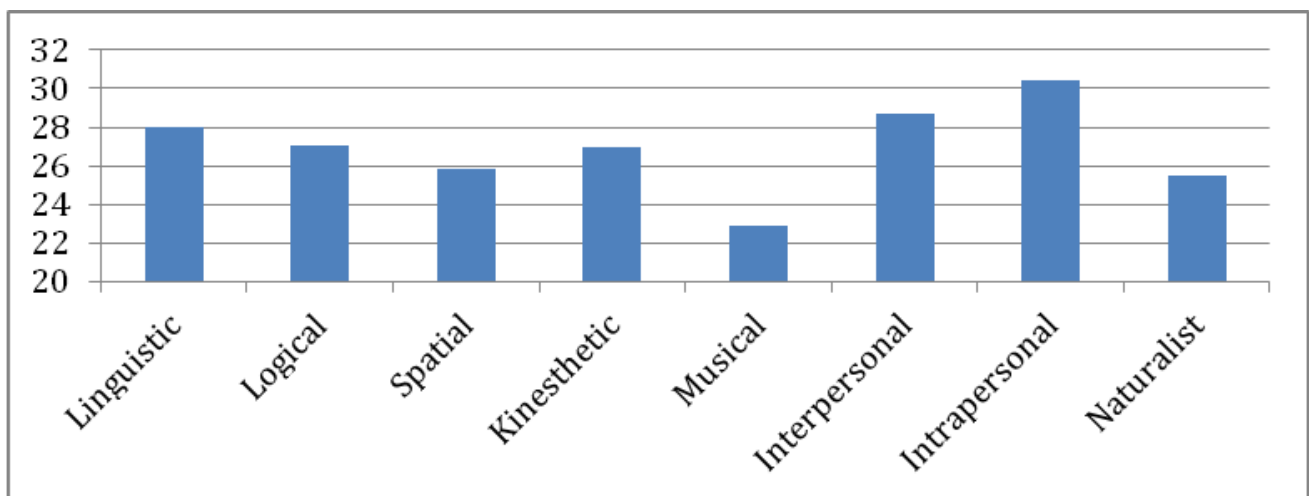

Figure 1: a column chart of the results

Table (3) shows that intrapersonal intelligence ranks first with a mean of (30.43) and STDEV of (4.5163) while Interpersonal intelligence lies at the second rank with a mean score of (28.663) and STDEV of (5.0003). The musical intelligence occupies the last rank with a mean of (22.93) and STDEV of (6.940).

The result of having the intrapersonal intelligence in the first rank can be attributed to the fact that the sample of the study belongs to the late adolescence stage. Based on the theory of Developmental Psychology of Erikson (1959), the sample of the study lies between stage number (5): Adolescence stage and stage number (6): Young Adult. During stage (5), adolescents major concern is finding their selves and determining their personal identity. They tried to explore the personal values and they start the first trial to set their future goals. In this period, they begin to construct their identity. In stage (6) the people begin to share their self-more intimately with others. They explore relationships leading toward longer-term commitments with someone other than a family member (McLeod,2017). 
The musical intelligence ranks last and this can be attributed to the fact that university environment is highly dominated by academic activities which are full of reports, seminars, projects, and exams. While the other activities such as musical events are just conducted on specific occasions such as the National day or graduation ceremony. There are no students' clubs for music or students' bands. Moreover, the Dhofar community is a conservative community consists of Tribes and clans which usually doesn't encourage or support Concerts or musical shows.

The results of the current study are in harmony with the results of the studies of Al- Faouri, Khataybeh, \& AlSheikh (2011) and Kandeel (2016) were in all studies the intrapersonal intelligence ranks first and interpersonal intelligence ranks second. The same results have been displayed in Alumran (2006), where the top three intelligence were interpersonal, intrapersonal, linguistic which is the exactly consistent with the result of this study. This study also is partially consistent with the result of the study of Mustafa, Abu Jado, \& Onoz (2014). In both studies, the interpersonal intelligence ranks second but the intrapersonal and linguistic intelligence exchanged the first and third position.

Regarding the musical intelligence, the students of this study give themselves the lowest score which also is in a full agreement with Al- Faouri, Khataybeh, \& Al-Sheikh (2011) where the musical intelligence ranks the last. In Alumran (2006), the musical intelligence ranks seventh out of nine intelligences while in Alumran (2006) study the existential intelligence has been also considered. In the study of Mustafa, Abu Jado, \& Onoz (2014), the musical intelligence ranks forth which represents a clear difference from other studies.

4.2: Findings and discussions of the second question::

The second question was: What are the multiple intelligences profiles DU students according to the gender? Table (4) shows means, standard deviation, and the rank of males and females while figure (2) shows a column chart of the results.

Table (4): multiple intelligences profiles of males and females of business students

Type of Intelligence Males Females

\begin{tabular}{lllllll} 
& Mean & STDEV & Rank & Mean & STDEV & Rank \\
\hline Linguistic & 27.31 & 4.461 & $3^{\text {rd }}$ & 28.61 & 4.371 & $3^{\text {rd }}$ \\
\hline Logical & 26.81 & 5.076 & $5^{\text {th }}$ & 27.25 & 3.960 & $4^{\text {th }}$ \\
\hline Spatial & 25.25 & 6.227 & $6^{\text {th }}$ & 26.31 & 4.394 & $6^{\text {th }}$ \\
\hline Kinesthetic & 27.03 & 4.177 & $4^{\text {th }}$ & 26.86 & 4.959 & $5^{\text {th }}$ \\
\hline Musical & 22.91 & 7.735 & $8^{\text {th }}$ & 22.94 & 6.261 & $8^{\text {th }}$ \\
\hline Interpersonal & 28.19 & 5.083 & $2^{\text {nd }}$ & 29.08 & 4.960 & $2^{\text {nd }}$ \\
\hline Intrapersonal & 30.03 & 4.490 & $1^{\text {st }}$ & 30.78 & 4.574 & $1^{\text {st }}$ \\
\hline Naturalist & 25.03 & 6.789 & $7^{\text {th }}$ & 25.89 & 5.301 & $7^{\text {th }}$
\end{tabular}

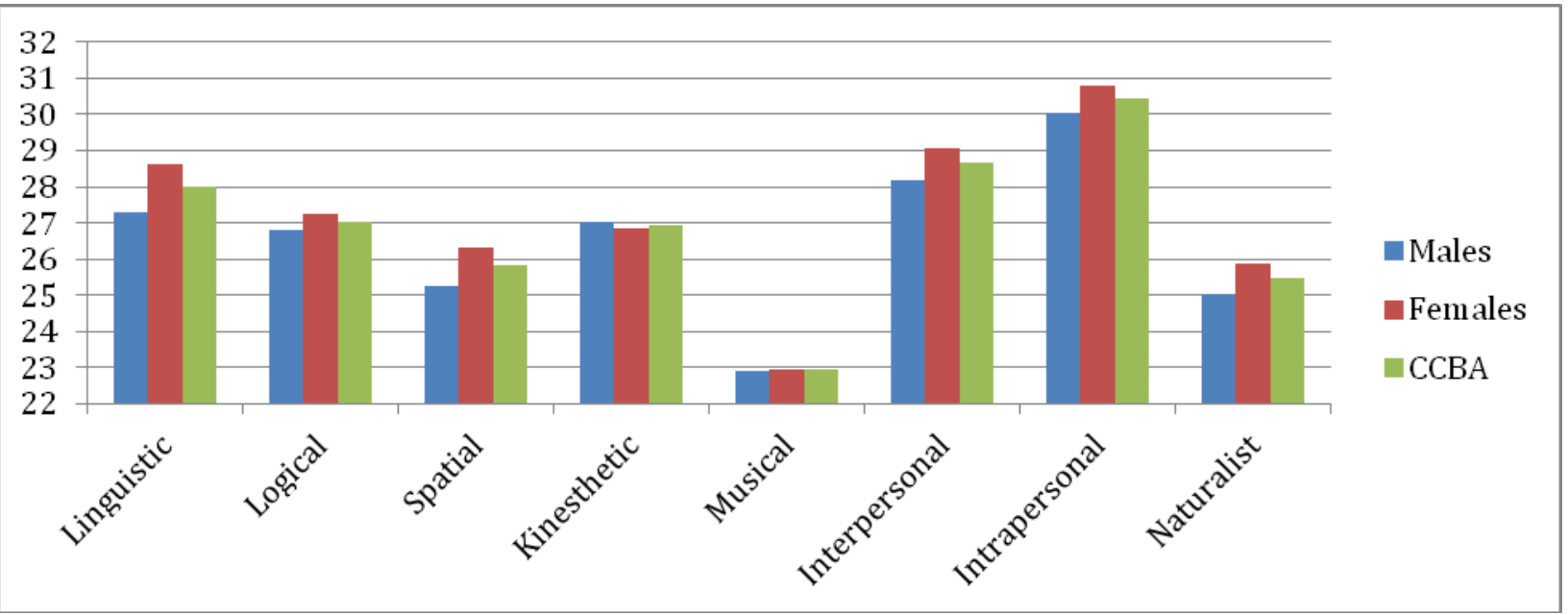

Figure (2): a column chart of males, females, and all sample results. 
According to the table (4), the males' intelligences ranked as follow: Intrapersonal, Interpersonal, Linguistic, Kinesthetic, Logical, Spatial, Naturalist, and finally the Musical intelligence. Regarding the females sample, the rank was as follows: Intrapersonal, Interpersonal, Linguistic, Logical, Kinesthetic, Spatial, Naturalist, and finally the Musical intelligence. In general, there is approximately full agreement in the ranks between males and females. The only difference is in Logical and Kinesthetic intelligence. Logical ranks 4th and Kinesthetic ranks 5 th in the female sample while. Logical ranks 5th and Kinesthetic ranks 4th in male sample.

Table (4) shows that females estimated their intelligences higher than males in all intelligences except in Kinesthetic intelligence. The result is in harmony of Chan (2003) but disagrees the result of Szymanowicz \& Furnham (2013) study, which reported that males consistently tend to rate their intelligence, especially mathematical intelligences higher than females. Finding out if the differences in the mean between males and females are significant or not, will be conducted later when discussing question number (5).

4.3: Findings and discussions of the third question: The third question was: What are the multiple intelligences profiles of business students according to the field of specialization? Table (5) shows means, standard deviation, and the rank for each specialization.

Table (5): multiple intelligences profiles of DU students according to the field of specialization

\begin{tabular}{|c|c|c|c|c|c|c|c|c|c|}
\hline & & Linguistic & Logical & Spatial & Kinesthetic & Musical & Interpersonal & Intrapersonal & Naturalist \\
\hline \multirow{3}{*}{$\begin{array}{l}\text { A\&F } \\
N=17\end{array}$} & Mean & 26.12 & 27.12 & 24.82 & 26.76 & 21.12 & 26.71 & 31.18 & 23.12 \\
\hline & Rank & $5^{\text {th }}$ & $2^{\text {nd }}$ & $6^{\text {th }}$ & $3^{\text {rd }}$ & $8^{\text {th }}$ & $4^{\text {th }}$ & $1^{\mathrm{st}}$ & $7^{\text {th }}$ \\
\hline & STDEV & 4.470 & 4.794 & 5.736 & 5.562 & 8.321 & 4.858 & 4.812 & 6.153 \\
\hline \multirow{3}{*}{$\begin{array}{l}M \& M \\
N=22\end{array}$} & Mean & 30.01 & 25.73 & 25.64 & 27.00 & 23.77 & 27.55 & 31.05 & 27.00 \\
\hline & Rank & $2^{\text {nd }}$ & $6^{\text {th }}$ & $7^{\text {th }}$ & $4^{\text {th }}$ & $8^{\text {th }}$ & $3^{\text {rd }}$ & $1^{\text {st }}$ & $5^{\text {th }}$ \\
\hline & STDEV & 4.146 & 5.166 & 5.786 & 4.231 & 6.256 & 4.657 & 5.038 & 6.362 \\
\hline \multirow{3}{*}{$\begin{array}{l}\text { MIS } \\
N=26\end{array}$} & Mean & 27.85 & 28.15 & 27.38 & 27.35 & 23.69 & 31.46 & 29.46 & 26.08 \\
\hline & Rank & $4^{\text {th }}$ & $3^{\text {rd }}$ & $5^{\text {th }}$ & $6^{\text {th }}$ & $8^{\text {th }}$ & $1^{\text {st }}$ & $2^{\text {nd }}$ & $7^{\text {th }}$ \\
\hline & STDEV & 3.906 & 3.529 & 4.041 & 4.214 & 6.291 & 4.178 & 3.911 & 5.283 \\
\hline \multirow{3}{*}{$\begin{array}{l}\text { CCBA } \\
\mathrm{N}=320\end{array}$} & Mean & 28.51 & 27.75 & 27.06 & 28.17 & 24.34 & 28.02 & 30.84 & 26.60 \\
\hline & Rank & $2^{\text {nd }}$ & $5^{\text {th }}$ & $6^{\text {th }}$ & $3^{\text {rd }}$ & $8^{\text {th }}$ & $4^{\text {th }}$ & $1^{\text {st }}$ & $7^{\text {th }}$ \\
\hline & STDEV & 4.325 & 4.923 & 5.042 & 4.530 & 5.854 & 4.754 & 4.254 & 5.046 \\
\hline
\end{tabular}

Referring to table (5), the following results have been revealed:

The multiple intelligences patterns of Accounting and Finance (A\&F) students appear in the following order: Intrapersonal, Logical, Kinesthetic, Interpersonal, Linguistic, Spatial, Naturalist, and Musical. Based on Armstrong (2009), the accountant should have a strong logical-mathematical intelligence. refereeing to table (5) the strongest intelligences in Accounting and Finance (A\&F) are intrapersonal intelligence and logicalmathematical intelligence. The result of this department shows that Accounting and Finance (A\&F) students are in the right specialization.

The multiple intelligences patterns of Management and Marketing (M\&M) students appear in the following order: Intrapersonal, Linguistic, Interpersonal, Kinesthetic, Naturalist, Logical, Spatial, and Musical. The students of Management and Marketing (M\&M) department should be strong in linguistic intelligence as well as interpersonal intelligence. Table (5) shows that linguistic ranks second and interpersonal intelligence ranks third. This confirms that the students of this department are in the right specialization.

Regarding Management Information Systems (MIS) department, The multiple intelligences patterns in the following order: Interpersonal, Intrapersonal, Logical, Linguistic, Spatial, Kinesthetic, Naturalist, and Musical. The case of Management Information Systems (MIS) is totally different. The students of this department should acquire a combination of intelligences in order to succeed in their study and their future profession. They should be strong in logical-mathematical intelligence to deal with Systems Analysis and Database Development. interpersonal and intrapersonal intelligence are very important in management, innovation and creativity. The profile of the students in this department shows that interpersonal ranks first, intrapersonal intelligence ranks second, logical-mathematical intelligence ranks third. The result confirms that the students of this department are absolutely in the right specialization. 
4.4: Findings and discussions of the fourth question: The fourth question is: What are the differences in the multiple intelligences profiles of business students in terms of gender, and field of specialization? To answer the question, MANOVA tests have been administered in light of the two variables: gender, and specialization.

4.5.1: From question number four, two hypotheses emerged. Starting with the first hypothesis which is: There are no statistically significant differences at $(\alpha=0.05)$ in the multiple intelligences of the profiles of business students attributed to the gender variable. One-way MANOVA tests of the differences between the means of sample score on the eight intelligences has been administered to find out if there are statistically significant differences in each intelligence according to gender variable. Table (6) shows the results:

Table (6): Multivariate Tests according to gender variable

\begin{tabular}{|l|l|l|l|l|l|l|l|}
\hline \multicolumn{2}{|l|}{ Effect } & Value & F & Hypothesis df & Error df & Sig. & $\begin{array}{l}\text { Partial Eta } \\
\text { Squared }\end{array}$ \\
\hline Gender & Wilks' Lambda & .966 & .259 & 8.000 & 59.000 & .977 & .034 \\
\hline
\end{tabular}

Table (6) shows that there is no statistically significant difference in intelligences based on gender, $F(8,59)=$ $0.259, p=0.977$; Wilk's $\Lambda=0.966$, partial $\eta^{2}=0.034$. Tests of (Between-Subjects Effects) confirms the same result. table (7) shows the details

Table (7): Tests of Between-Subjects Effects

\begin{tabular}{|l|l|l|l|l|l|l|l|}
\hline $\begin{array}{l}\text { Source of } \begin{array}{l}\text { Variance } \\
\text { Variable }\end{array} \\
\text { Vependent }\end{array}$ & $\begin{array}{l}\text { Sum of } \\
\text { Squares }\end{array}$ & $\begin{array}{l}\text { Degrees of } \\
\text { Freedom }\end{array}$ & $\begin{array}{l}\text { Means of } \\
\text { Squares }\end{array}$ & $\begin{array}{l}\text { F } \\
\text { Value }\end{array}$ & $\begin{array}{l}\text { Statistical } \\
\text { Significant }\end{array}$ & $\begin{array}{l}\text { Partial } \\
\text { Eta } \\
\text { Squared }\end{array}$ \\
\hline \multirow{4}{*}{ Gender } & Linguistic & 28.569 & 1 & 28.569 & 1.467 & .230 & .022 \\
\cline { 2 - 8 } & Logical & 3.243 & 1 & 3.243 & .159 & .692 & .002 \\
\cline { 2 - 8 } & Spatial & 18.876 & 1 & 18.876 & .663 & .418 & .010 \\
\cline { 2 - 8 } & Kinesthetic & .490 & 1 & .490 & .023 & .880 & .000 \\
\cline { 2 - 8 } & Musical & .025 & 1 & .025 & .001 & .982 & .000 \\
\cline { 2 - 8 } & Interpersonal & 13.596 & 1 & 13.596 & .540 & .465 & .008 \\
\cline { 2 - 8 } & Intrapersonal & 9.441 & 1 & 9.441 & .459 & .500 & .007 \\
\cline { 2 - 8 } & Naturalist & 12.461 & 1 & 12.461 & .341 & .561 & .005 \\
\hline
\end{tabular}

The table above shows that there are no statistically significant differences in any intelligence according to gender. This result is in agreement with the result of Chan (2003).

At the same time the result of the study is in disagreement with the studies of Furnham \& Ward, (2001): Furnham, Tang, Lester, O’Connor, \& Montgomery, (2002); Weiss, Kemmler, Deisenhammer, Fleischhacker, \& Delazer, (2003) which explain that there are statistically significant differences between males and females in all intelligences in favor of males. Also, it is in disagreement with Farunham \&Akande (2004) which shows that the females perform better than males in all intelligences.

4.5.2: The second hypothesis: There are no statistically significant differences at $(\alpha=0.05)$ in the multiple intelligences of the profiles of DU students attributed to the specialization variable. One-way MANOVA tests of the differences between the means of sample score on the eight intelligences has been administered to find out if there are statistically significant differences in each intelligence according to specialization variable. Table (8) shows the results:

Table (8): Multivariate Tests

\begin{tabular}{|l|l|l|l|l|l|l|l|}
\hline \multicolumn{2}{|l|}{ Effect } & Value & F & $\begin{array}{l}\text { Hypothesis } \\
\text { df }\end{array}$ & Error df & $\begin{array}{l}\text { Sig. } \\
\text { Partial } \\
\text { Eta } \\
\text { Squared }\end{array}$ \\
\hline Specialization & Wilks' Lambda & .456 & 3.485 & 16.000 & 116.000 & .000 & .325 \\
\hline
\end{tabular}

Table (8) shows that there are a statistically significant differences in intelligences based on specialization, $F$ (16, 116) $=3.485, p<.0005$; Wilk's $\Lambda=0.456$, partial $\eta^{2}=0.325$.

To determine how the intelligences variable differs for the specialization variable, we need to look at the Tests of Between-Subjects Effects table (9): 
Table (9): Tests of Between-Subjects Effects

\begin{tabular}{|l|l|l|l|l|l|l|l|}
\hline $\begin{array}{l}\text { Source } \\
\text { Variance }\end{array}$ & $\begin{array}{l}\text { Dependent } \\
\text { Variable }\end{array}$ & $\begin{array}{l}\text { Sum of } \\
\text { Squares }\end{array}$ & $\begin{array}{l}\text { Degrees of } \\
\text { Freedom }\end{array}$ & $\begin{array}{l}\text { Means of } \\
\text { Squares }\end{array}$ & $\begin{array}{l}\text { F } \\
\text { Value }\end{array}$ & $\begin{array}{l}\text { Statistical } \\
\text { Significant }\end{array}$ & $\begin{array}{l}\text { Partial } \\
\text { Eta } \\
\text { Squared }\end{array}$ \\
\hline \multirow{5}{*}{ Specialization } & Linguistic & 176.711 & 2 & 88.355 & 5.050 & .009 & .134 \\
\cline { 2 - 8 } & Logical & 70.169 & 2 & 35.085 & 1.781 & .177 & .052 \\
\cline { 2 - 8 } & Spatial & 134.320 & 2 & 67.160 & 2.477 & .092 & .071 \\
\cline { 2 - 8 } & Kinesthetic & 11.330 & 2 & 5.665 & .265 & .768 & .008 \\
\cline { 2 - 8 } & Musical & 105.230 & 2 & 52.615 & 1.096 & .340 & .033 \\
\cline { 2 - 8 } & Interpersonal & 347.555 & 2 & 173.777 & 8.508 & .001 & .207 \\
\cline { 2 - 8 } & Intrapersonal & 39.216 & 2 & 19.608 & .960 & .388 & .029 \\
\cline { 2 - 8 } & Naturalist & 178.189 & 2 & 89.095 & 2.578 & .084 & .073 \\
\hline
\end{tabular}

Error $=65$

From table (9) we see that only two intelligences have a statistically significant effect on specialization variable. Linguistic intelligence has a statistically significant effect on specialization variable $(F(2,65)=5.050 ; p<0.05$; partial $\left.\eta^{2}=0.134\right)$ and Interpersonal intelligence has a statistically significant effect on specialization variable $\left(F(2,65)=8.508 ; p<0.05 ;\right.$ partial $\left.\eta^{2}=0.207\right)$.

To determine which of the means for the three (3) specializations are significantly different from the others in the two intelligences above, Post Hoc Analysis (Tukey) has been administered. Table (10) shows the results for the intelligences that have a statistically significant effect on specialization variable (Linguistic, and Interpersonal).

Table (10): Post Hoc Analysis (Tukey)

\begin{tabular}{|l|l|l|l|}
\hline \multicolumn{2}{|l|}{ Linguistic } & \multicolumn{2}{l|}{ Interpersonal } \\
\hline statistically significant differences & \multicolumn{2}{|l|}{ statistically significant differences } \\
\hline M\&M Vs A\&F & $4.10^{*}$ & MIS Vs A\&F & $5.21^{*}$ \\
\hline & & MIS Vs M\&M & $3.92^{*}$ \\
\hline
\end{tabular}

* Significant at $(\alpha=0.05)$.

Table (10) shows that the differences in the means are significant between $M \& M$ and A\&F in favor of M\&M. Regarding Interpersonal intelligence, the differences between the means of MIS in one hand and all A\&F and M\&M on the other hand, are significant in favor of MIS specialization.

\section{Conclusions and Recommendations:}

The result of the study shows that intrapersonal intelligence has the highest score and ranks first always. The other intelligences have the following order: Interpersonal, Linguistic, Logical, Logical, Kinesthetic, Spatial, Naturalist, and musical intelligences, respectively. This shows that students have a good ability to understand themselves, goals, strengths and weakness, and interests. Also, the result shows that there are no statistically significant differences between boys and girls in all intelligences. Regarding specialization variable, the study finds that there are statistically significant differences in Linguistic intelligence between the means of M\&M and $\mathrm{A} \& \mathrm{~F}$ in favor of M\&M and in Interpersonal intelligence between the means of MIS in one hand and all A\&F and M\&M on the other hand, are significant in favor of MIS specialization. Despite having a regular and official musical period in both private and public school in Oman, the musical intelligence comes in the last order. This result is frustrating and the authors invite the decision makers in Ministry of Education to evaluate the efficiency of the musical period in the school and try to improve the performance of the students in music.

In the light of the results of this study the researchers recommend the following:

1. The professors of Omani universities are advised to adjust their syllabi and teaching Styles based on the dominant multiple intelligences among their students.

2. Advisors of students are invited to use multiple intelligences scale to direct their students to the specialization that is appropriate for their intelligence profiles.

3. In case the students are weak in an important intelligence for a certain specialization, the department should plan and design activities to develop the desired intelligence. 


\section{References}

Abdulkarim, R., Al Jadiry, A. (2012). The Effect of Cooperative Learning Group Division Based on Multiple Intelligences Theory and Previous Achievement on Scientific Thinking Skills Development of Ninth Grade Students in Oman. European Journal of Social Sciences, Vol. 27(4), 553-569.

Ahmad, M. A. (2010). The impact of a program based on multiple intelligences in developing creative thinking and achievement among students of the commercial secondary school. Unpublished M.A thesis, The Institute of Educational Studies, University of Cairo, Egypt.

Al-Aslani, R. M. (2010). The effectiveness of a remedial strategy in light of multiple intelligences on developing geometry achievement and attitudes towards geometry among 2 nd preparatory slow learners in Jeddahgovernorate. Unpublished Ph. D thesis, Females Faculty of Education, Jeddah, Saudi Arabia.

Al-Faoury, O., Khataybeh, A. \& Al-Sheikh, K. (2011). Multiple Intelligences Of Students At Jordanian Universities. Journal of International Education Research, Vol. 7 (4), 83-94.

Alumran, j. (2006). Multiple Intelligences for Bahraini Students at the University Level According to Gender and Academic Specializations: Is the Right Student in the Right Specialization? Journal of Educational and Psychological Sciences. University of Bahrain. Vol. 7(3). 13-43.

Armstrong, T. (2009). Multiple Intelligences in the Classroom (3rd ed.). Alexandria: ASCD.

Chan, D. (2003). Multiple intelligences and perceived self-efficacy among Chinese secondary school teachers in Hong Kong. Educational Psychology, 23(5), 521-533. https://doi.org/10.1080/0144341032000123778.

Gardner, H. (1983). Frames of Mind: The Theory of Multiple Intelligences. New York: Basic Books

Gardner, H. (1993). Multiple Intelligences: The Theory in Practice. New York: Basic Books.

Gardner, H (1995). Reflections on multiple intelligences: Myths and messages. Phi Delta Kappan, 77(3), 200210.

Gardner, H. (1999). Intelligence Reframed: Multiple Intelligences for the 21 st Century. New York: Basic Books.

Gardner, H. (2011). Frames of Mind: Multiple Intelligences. (3rd Ed.). New York: Basic Books.

Fardad, Z, Koosha, M., \& Shafiee, S. (2015). Relationship between EFL Learners' Multiple Intelligence Scores, Gender, and Their Vocabulary Knowledge. Research Journal of Recent Sciences Vol. 4(12), 29-36.

Furnham, A., \& Akande, A. (2004). African parents' estimates of their own and their children's multiple intelligence. Current Psychology: Developmental, Learning, Personality, Social, 22(4).281-294.

Furnham, A. \& Ward, W. (2001). Sex differences, test experience, and the self-estimation of multiple intelligences. New Zealand Journal of Psychology, 30,52-59.

Furnham, A., Tang, T., Lester, D., O’Connor, R., \& Montgomery, R. (2002). Self-estimates of ten multiple intelligences. Sex and National differences and the perception of famous people. European Psychologist, 7, 245-255. https://doi.org/10.1027//1016-9040.7.4.245

Kallenbach, S. (2006). Emerging themes in adult multiple intelligences research. Focus on Basics, 3, (A), 16-20.

Kandeel, R. (2016). Multiple Intelligences Patterns among Students at King Saud University and Its Relationship with Mathematics' Achievement. Journal of Education and Learning, Vol. 5(3), 94-106. https://doi.org/10.5539/jel.v5n3p94.

McLeod, S. (2017). Erik Erikson. Retrieved from: https://www.simplypsychology.org/Erik-Erikson.html

McKenzie, W. (1999). Multiple Intelligences Survey Retrieved from http://surfaquarium.com/MI/ Mlinvent.htm.

Mustafa, S., Abu Jado, S. and Onoz, S. (2014). Types of Multiple Intelligences among Undergraduate Students at Yarmouk University in Light of Gardner's Theory. International Journal of Humanities and Social Science, Vol. 4(6), 140-153.

Sternberg, R.J. (1990). Metaphors of mind: Conceptions of the nature of intelligence. Cambridge: New York: Cambridge University Press.

Szymanowicz, A., Furnham, A. (2013). Gender and Gender Role Differences in Self- and Other-Estimates of Multiple Intelligences. The Journal of Social Psychology. Vol. 153(4): 399-423. https://doi.org/10.1080/00224545.2012.754397.

Weiss, E.M., Kemmler, G., Deisenhammer, E.A., Fleischhacker,W. \& Delazer, M. (2003). Sex differences in cognitive functions. Personality and Individual Differences, 35 (4), 863-875. https://doi.org/10.1016/S0191-8869(02)00288-X.

Wechsler, D. (1944). The measurement of adult intelligence (3rd ed.). Baltimore: Williams \& Wilkins. https://doi.org/10.1037/11329-000. 